\title{
THE EUROPEAN POLLEN DATABASE: A BRIEF REVIEW
}

\author{
SHEILA HICKS and ELISABETH GRÖNLUND
}

HICKS, SHEILA and GRÖNLUND, ELISABETH, 1994. The European pollen Database: A brief review. Bull. Geol. Soc. Finland 66, Part 2, 129-136.

The history and function of the European Database are described and the Finnish contributions as of March 1994 are listed. Reference is made to the relevant computer software and to recommendations with respect to pollen nomenclature.

Keywords: pollen, data bases, pollen diagrams, nomenclature, Quaternary, Europe, Finland.

Sheila Hicks Department of Geolsciences and Astronomy University of Oulu, Linnanmaa, FIN-90570 OULU.

Elisabeth Grönlund Karelian Institute, Section of Ecology, University of Joensuu, Box 111, FIN-80101 JOENSUU

\section{INTRODUCTION}

The European Pollen Database (EPD) is a database of pollen counts collected as pollen diagrams, that is from stratigraphic sequences. It should not be confused with the European Pollen Databank (situated in Vienna), which is a databank of airborne pollen counts and is used in monitoring pollen conditions on a daily or weekly basis for allergy sufferers.

The idea to establish the EPD was brought forward in 1989 following the initiation of a similar database for North America. Its aim is twofold. Firstly to have a place in which the valuable data 
that goes to make up pollen diagrams can be stored in its raw form so that it is not lost to the scientific world and secondly to collect together data for the whole of Europe so that syntheses and analyses can be made in time and space for specific species of plant communities. This means that one aspect is in terms of contribution and another in terms of use. It is hoped that researchers will take advantage of both aspects but it is also realised that some may be primarily contributors and others primarily users. In order to forestall any difficulties which may arise through this dichotomy a set of protocols (see Table I) was drawn up in 1990, i.e. before data collection commenced, and these guidelines and restrictions are still in force today.

The database itself is situated in Arles, France (Address: European Pollen Database Centre, Universitaire d'Arles, Place de la République, 13200 Arles, FRANCE) and was officially opened for use in March 1994. Data is submitted in Tilia form (both the Tilia and Tilia.graph programs are available from Eric C. Grimm, Research and Collections Center, Illinois State Museum, 1920 South 101/2 Street, Springfield, IL 62703, USA) and the software for using it is in Paradox (available from the EPD Centre). Because of the need to be able to compare different areas of Europe at given points in time, only pollen diagrams which are supplemented by ${ }^{14} \mathrm{C}$ dates, or which have some other firm chronostratigraphy, are included. Also, to insure a certain standard of reliability in comparing a set of diagrams, those with a relatively close sampling interval and high pollen count are preferred. In addition to the raw pollen data, for each site submitted background data about location, height, vegetation etc. is given on a set of paper forms and this information is incorporated in the database.

Initially the database was intended to cover the Weichselian late-glacial and the Holocene but there is now a separate database for material designated as Eemian and one is being developed for sites which have been assigned to the Holsteinian/ Hoxnian. It is also envisaged that, in future, there will be a database of modern pollen deposition. During the period 1990-1994, which has been the main period for developing the system and collecting the first data contributions, different centres in Britain, France and The Netherlands took on the physical job of data compilation but now all the data is gathered together in Arles.

\section{ADMINISTRATION OF THE EPD}

The EPD has an Executive Committee of three, whose job is to secure finance and to ensure that the day to day running of the database can progress smoothly. There is no firm source, as yet, of long-term financial support. Much of the initial compilation has been through variously funded projects and it has been possible to employ only one person to work with the database in Arles on a full-time basis. There is also an Advisory Board of 13 scientists (including the three Executive Committee members) whose job is to draw up the guidelines along which the database functions and to dispense information between palynologists in the different European countries. The Advisory Board members together cover a range of palynological expertise and (at present) are drawn from the following countries: France, Switzerland, UK (2), Norway, The Netherlands (2), Bulgaria, Finland, USA, Poland, Lithuania and Germany. The Chairman of the Advisory Board acts as liaison officer and is responsible for ensuring that information moves quickly and efficiently between the various administrative members and the database users and contributors.

The EPD produces a newsletter for circulation among the European palynological community at large in which it reports on developments in the database itself, decisions made by the Executive Committee and Advisory Board, meetings etc. The database centre at Arles, in addition to giving help and advise by post, fax or e-mail is also happy to receive visitors requiring first-hand instruction on 


\title{
PROTOCOLS FOR THE EUROPEAN POLLEN DATABASE
}

\author{
22nd September 1990 - Wilhelmshaven
}

The following protocols for the database were discussed and agreed by the Advisory Board at its meeting in Wilhelmshaven. In the event that it becomes necessary to modify them in the future, all database contributors and users will be notified and the changes will be published in the Newsletter.

\section{A. Data}

1. Data must consist of the original counts, not percentages or digitized data.

2. Database must contain the original taxonomic identifications, with exceptions of exact nomenclatural synonymy. Taxa will not be lumped into higher taxonomic groups in the database.

3. Data will be classified as unrestricted or restricted. All data will be available in the database. In other words, the central database will distribute all data, restricted and unrestricted. Thus, restricted data can be viewed by a user, but cannot be used except as provided below.

4. Unrestricted data are available for all uses.

5. Restricted data may be used only by permission of the data originator. Appropriate and ethical use of restricted data is the responsibility of the data user.

\section{B. Contributors}

1. Can declare data unrestricted or restricted.

2. Can ask to verify that data in the database are correct. As a matter of general policy, the central database should routinely return to the data originator a hardcopy printout of the data as they are entered in the database for optional verification by the originator.

3. May use any unrestricted data.

4. Can obtain copies of application software and the database itself for use on his/her own computer.

5. Should receive a periodic newsletter or report concerning the database.

6. Can ask at any time that his/her data be withdrawn from the database or that their status (unrestricted or restricted) be changed.

7. In the case of a dispute regarding inappropriate use of restricted data, the Advisory Board will serve as arbitrator.

\section{Users}

1. Must ask permission from the data originator for use of restricted data.

2. Should, as a matter of courtesy, inform data originators of the uses being made of their data.

3. If the contributor wishes, should show the contributor results of analyses and manuscripts for publication for critical comment.

4. Should cite, in any publication using data from the database, the contributors' original publications describing their data.

5. Should send contributors reprints of publications that use their data.

6. Should acknowledge contributors for use of unpublished data and for any advice they may have provided.

7. No user can pass data on to another party. All users must obtain data from the central database. 8. Normal ethics apply to co-authorship of publications. The contributor should be invited to be a co-author if a user makes significant use of a single contributor's data, or a single contributor's data comprise a substantial portion of a larger dataset analyzed, or a contributor makes a significant contribution to the analysis of the data or to the interpretation of the results. This guideline applies to unrestricted as well as to restricted data.

9. The data are available only to non-profit-making organizations and for research. Profit-making organizations may use the data, even for legitimate uses, only with the written consent of the Advisory Board, who will determine or negotiate the payment of any fee required. 
both the Tilia program and the use of the database.

\section{THE FINNISH SITUATION}

Finnish palynologists have shown an active interest in the EPD since its initiation. It has also been felt that, rather than try to establish a separate Finnish pollen database (as some countries eg. Poland, are doing) all Finnish Quaternary pollen data can most easily and conveniently be sent to Arles and, when needed, just as easily retrieved from there.

So as to speed up the entering of older pollen data (from before the Tilia era) the Joensuu team have developed a program called Epollen. For each depth it is only necessary to enter the numerical code for a pollen type followed by the number of grains counted for that type. Epollen then converts the completed data sheet to Tilia format.

In order to facilitate data collection the ESF gave some financial assistance to each of the participating countries. Finland received her share and through this it was possible to employ an assistant to assemble data (using the Epollen program) so that by the time of the opening of the database the Finnish contribution consisted of 32 Finnish sites (see map in Fig. 1 and Table II) and 4 sites from the far north of Norway.

It is evident from Fig. 1. that the distribution of the Finnish data is very uneven. There are a variety of reasons for this.

1) Sites have been investigated but the data has not been submitted. This is particularly the case in the south and east of the country and will be partly remedied in the future when possibilities become available for entering old data into Tilia format.

2) The areas simply have not yet been investigated (eg. in the north of the country) or are in the process of being investigated (northern Lapland and the central parts of the country).

3) The areas fit badly into the database framework. This is true of the very coast where deposits are often too young (the stratigraphic sequence is too short) or difficult to date accurately by $14 \mathrm{C}$.

The unevenness of the Finnish data perhaps requires a few words of caution if analyses are to be made on just this data set. Because the country is of considerable length in a north-south direction and thus incorporates quite big variations in both climate and vegetation it would be wrong to extrapolate between widely spaced data points. Also, because of the great latitudinal extent and very northern location vegetation development has, in general, progressed from south to north but with some elements migrating from east to west and, in the later part of the Holocene, a certain degree of retraction has taken place from north to south. In tracing the history of one particular species, therefore, the accuracy of the dating is a critical factor. Lastly, it should be remembered that a number of the pollen diagrams included in the database were produced in order to trace anthropogenic influence on the vegetation and, therefore, that data may not accurately represent natural vegetation development.

\section{A FOOTNOTE ON POLLEN NOMENCLATURE}

During the initial compilation stage of the database it became evident that it would be necessary to have some sort of standardization of the nomenclature employed in order for the database to be used in a logical way. A group of 9 experts was appointed to do this and they have now produced a dictionary which the Arles centre can refer to as data is complied. This is an important tool for the smooth functioning of the database but it is not intended as a 'standard list' for general distribution. It is felt that palynologists should be encouraged to identify their pollen types to different levels of precision in keeping with the problems they are dealing with and the reference data that they have available. The greater precision of the identification the more 
Figure 1. Location of Finnish pollen sites submitted to the European Pollen

Database by March, 1994 (see Table II).

Vegetation zones

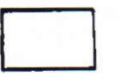

Northern boreal zone

$\because \because$ Middle boreal zone

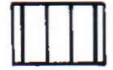

Southern boreal zone

Hemiboreal zone

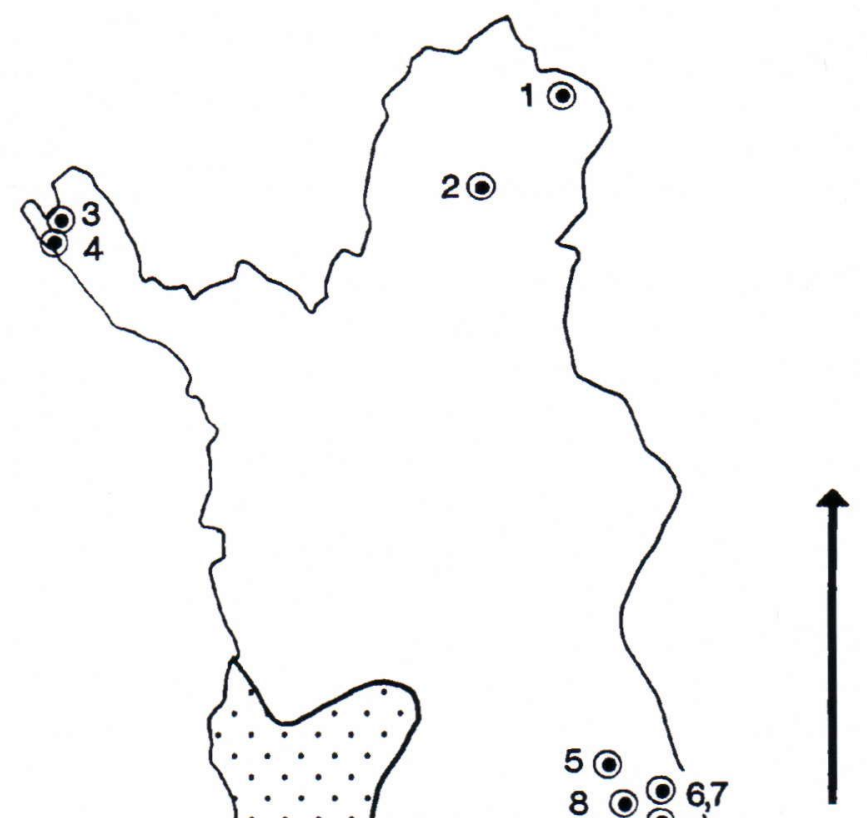

- Data site

\section{${ }^{28} \operatorname{cog} 29$}

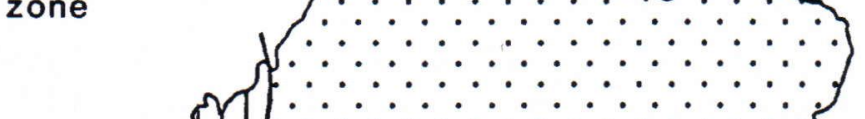


Table 2.

\section{Sites submitted to the European Pollen Database as of March, 1994 (in latitudinal order from north to south, see Fig. 1.)}

\author{
Domsvatnet (Norway) $\quad 70^{\circ} 19^{\prime} \mathrm{N} 31^{\circ} 02^{\prime} \mathrm{E}$ \\ Hyvärinen, H. (1976) \\ Boreas 5, 163-175.
Bruvatnet (Norway) $\quad 70^{\circ} 11^{\prime} \mathrm{N} 28^{\circ} 25^{\prime} \mathrm{E}$ Hyvärinen, H. (1975)
Fennia 142, 1-23.

Trollvatnet (Norway) $\quad 69^{\circ} 52^{\prime} 30^{\prime \prime} \mathrm{N} 23^{\circ} 28^{\prime} \mathrm{E}$ Hyvärinen, H. (1985)

Ecologia Mediterranea 11, 69-71.

1) Suovalampi, Inari. $69^{\circ} 35^{\prime} \mathrm{N} 28^{\circ} 50^{\prime} \mathrm{E}$ Hyvärinen, H. (1975)

Fennia 142, 1-23.

Råttuvarri (Norway) $\quad 69^{\circ} 21^{\prime} \mathrm{N} 20^{\circ} 19^{\prime} \mathrm{E}$ Eronen, M. and Hyvärinen, H. (1982) GFF 103, 437-455.

2) Akuvaara, Inari. $69^{\circ} 07^{\prime} 30^{\prime \prime} \mathrm{N} 27^{\circ} 41^{\prime} \mathrm{E}$ Hyvärinen, H. (1975)

Fennia 142, 1-23.

3) Masehjavri, Enontekiö. $69^{\circ} 03^{\prime} \mathrm{N} 20^{\circ} 59^{\prime} \mathrm{E}$ Hyvärinen, H. (1992)

Paläoklimaforschung 9, 19-27.

4) Mukkavaara, Enontekiö. $68^{\circ} 55^{\prime} \mathrm{N} 21^{\circ} 00^{\prime} \mathrm{E}$ Eronen, M. and Hyvärinen, H. (1982) GFF 103, 437-455.

5) Kolmiluokkonen, Posio. $66^{\circ} 14^{\prime} \mathrm{N} 28^{\circ} 29^{\prime} \mathrm{E}$ Huttunen, A. Unpublished

6)Valtavaaranlampi, Kuusamo. $66^{\circ} 10^{\prime} \mathrm{N} 29^{\circ} 11^{\prime} \mathrm{E}$ Huttunen, A and Huttunen, R. (1989) Oulangan biologisen aseman monisteita 13, 19-24.

7) Rukatunturi, Kuusamo. $66^{\circ} 10^{\prime} \mathrm{N} 29^{\circ} 9^{\prime} \mathrm{E}$ Hicks, S. (1974)

Mem. Soc. Fauna Flora Fenn. 49, 21-33.

8) Kangerjoki, Kuusamo. $66^{\circ} 7^{\prime} \mathrm{N} 29^{\circ} 0^{\prime} \mathrm{E}$ Hicks, S. (1975)

Comment. Biol. 30, 4-28.
9) Särkikangas, Kuusamo. $65^{\circ} 55^{\prime} \mathrm{N} 29^{\circ} 12^{\prime} \mathrm{E}$ Hicks, s. (1976)

Trans. IBG New Series 1, 362-384.

10) Maanselänsuo, Kuusamo. $65^{\circ} 37^{\prime} N 29^{\circ} 36^{\prime} \mathrm{E}$ Vasari, Y. (1965)

Anna. Bot. Fenn. 2, 219-235.

11) Sipola, Hailuoto. $\quad 65^{\circ} 03^{\prime} N 24^{\circ} 47^{\prime} 30^{\prime \prime} E$ Hicks, S. (1992)

Vegetation History and

Archaeobotany 1, 75-86.

12) Kittilä, Hailuoto. $\quad 65^{\circ} 01^{\prime} 30^{\prime \prime} \mathrm{N} 24^{\circ} 41^{\prime} \mathrm{E}$ Hicks, S. (1992)

Vegetation History and

Archaeobotany 1, 75-86.

13) Vasikkasuo, Puolanka. $64^{\circ} 40^{\prime} \mathrm{N} 27^{\circ} 52^{\prime} \mathrm{E}$ Vuorela, I. (1992)

14) Heinälampi, Siilinjärvi. $63^{\circ} 07^{\prime} \mathrm{N} 27^{\circ} 39^{\prime} \mathrm{E}$ Grönlund, E. (1991)

HYdrobiologia 214, 137-142

Suo 42, 101-108.

15) Mäyrälampi, Hankasalmi. $62^{\circ} 20^{\prime} N 26^{\circ} 14^{\prime} E$ Koivula, L. Unpublished

16) Pitkälampi, Tohmajärvi.62 ${ }^{\circ} 15^{\prime} \mathrm{N} 30^{\circ} 30^{\prime} \mathrm{E}$ Grönlund, E. and Asikainen, E. (1992) Laborativ Arkeologi 6, 43-48

17) Ylimysneva, Parkano. $62^{\circ} 08^{\prime} \mathrm{N} 22^{\circ} 52^{\prime} \mathrm{E}$ Huttunen, A. (1990)

Aquilo Ser. Bot. 28, 27-37.

18) Aholammi, Jämsä. $\quad 61^{\circ} 53^{\prime} \mathrm{N} 25^{\circ} 13^{\prime} \mathrm{E}$ Koivula, L. Unpublished

19) Kaakotinlampi, Sysmä. $61^{\circ} 25 \mathrm{~N} 25^{\circ} 52^{\prime} \mathrm{E}$ Vuorela, I. (1981)

Bull. Geol. Soc. Finland 53, 47-61.

20) Tullerinsuo, Nakkila. $61^{\circ} 20^{\prime} \mathrm{N} 21^{\circ} 57^{\prime} \mathrm{E}$ Vuorela, I. (1991)

Karhunhammas 13, 2-23. 
21) Siikasuo, Harjavalta. $61^{\circ} 18^{\prime} \mathrm{N} 22^{\circ} 04^{\prime} \mathrm{E}$ Vuorela, I. (1991)

Karhunhammas 13, 2-23.

22) Syrjälänsuo, Taipalsaari. $61^{\circ} 13^{\prime} \mathrm{N} 28^{\circ} 07^{\prime} \mathrm{E}$ Vuorela, I. Unpublished

23) Kirkkosaari, Janakkala. $60^{\circ} 52^{\prime} \mathrm{N} 24^{\circ} 30^{\prime} \mathrm{E}$ Rankama, T. and Vuorela; I. (1988) Mem. Soc. Fauna Flora Fenn. 64, 25-34.

24) Kuivajärvi, Tammela. $60^{\circ} 47^{\prime} \mathrm{N} 23^{\circ} 50^{\prime} \mathrm{E}$ Vuorela, I. Unpublished

25) Kaartlamminsuo, Loppi. $60^{\circ} 44^{\prime} \mathrm{N} 24^{\circ} 13^{\prime} \mathrm{E}$ Rankama, T. and Vuorela; I. (1988) Mem. Soc. Fauna Flora Fenn. 64, 25-34.

26) Hirvilampi, Lappi. $\quad 60^{\circ} 37^{\prime} 3 " \mathrm{~N} 24^{\circ} 15^{\prime} \mathrm{E}$ Rankama, T. and Vuorela; I. (1988) Mem. Soc. Fauna Flora Fenn. 64, 25-34.

27) Ryönänsuo, Vihti. $60^{\circ} 26^{\prime} \mathrm{N} 24^{\circ} 10^{\prime} \mathrm{E}$ Rankama, T. and Vuorela, I. (1988) Mem. Soc. Fauna Flora Fenn. 64, 25-34.
28) Kvarnträsk, Finström. $60^{\circ} 21^{\prime} \mathrm{N} 19^{\circ} 59^{\prime} \mathrm{E}$ Sarmaja-Korjonen, K., Vasari, Y. and Haeggström, C.-A. (1991) Ann. Bot. Fenn. 28, 143-159.

29) Kolmilaträsk, Saltvik. $60^{\circ} 17^{\prime} \mathrm{N} 20^{\circ} 9^{\prime} \mathrm{E}$ Sarmaja-Korjonen, K., Vasari, Y. and Haeggström, C.-A. (1991) Ann. Bot. Fenn. 28, 143-159.

30) Isokärret, Kemiä. $\quad 60^{\circ} 13^{\prime} \mathrm{N} 22^{\circ} 8^{\prime} \mathrm{E}$ Asplund, H. and Vuorela, I. (1989) Fennoscandia Archaeologica 6 , 67-79.

31) Lalaxkärret, Nouvo. $60^{\circ} 09^{\prime} \mathrm{N} 21^{\circ} 52^{\prime} \mathrm{E}$ Vuorela, I. (1990) Studier i åboländsk kulturhistoria utgivina av konstsamfundet till dess 50-årsjubileum pp. 115-133.

32) Mossen, Korppoo. $60^{\circ} 07^{\prime} \mathrm{N} 21^{\circ} 36^{\prime} \mathrm{E}$ Vuorela, I. (1990) Studier i åboländsk kulturhistoria utgivina av konstsamfundet till dess 50-årsjubileum pp. 115-133. precise the ecological interpretation that is possible. However, everyone wishes to standardize nomenclature in a way that enables comparisons between different workers easier. The pollen nomenclature working group offers the following guidelines:

A) Use the terminology of one of the followingpublications and state which one.

Northwest European Pollen Flora, by Punt et al. Pollen analysis by Moore, Webb and Collins. Textbook of Pollen Analysis by Faegri and Iversen. Leitfaden der Pollenbestimmung, by Beug. Identification of wild grass and cereal pollen by Andersen.

Pollen et Spores d'Europe et d'Afrique du Nord by
Reille.

B) Follow the nomenclature practice outlined by Birks, 1973 (see aslo Berglund, 1986) namely:

1. The pollen type has only one species.

Example: Cladium mariscus

2. Family determination certain, no further distinction.

Example: Gramineae

3. Genus determination certain, no further distinction.

Example: Abies

4. A pollen type represents two genera.

Example: Alchemilla/Aphanes

5. A pollen type represents two species. Example: Plantago major/P. media 
6. A pollen type represents more than two plant taxa.

Example: Liliaceae-type

Anthemis-type

Gentiana pneumonanthe-type

C) The biggest difficulties are experienced with the extension '-type' or the prefix 'cf' when they are used in the sense that the identification is uncertain. If you use '-type' (other than in the instance of 6

\section{REFERENCES}

Andersen, S.T., 1979. Identification of wild grass and cereal pollen. Danm. Geol. Unders. Årb. 1978, 69-92.

Birks, H.J.B., 1973. Past and Present Vegetation of the Isle of Skye: a Palaeoecological Study. Cambridge University Press, London. 415 pp

Berglund, B.E., 1986. Handbook of Holocene Palaeoecology and Palaeohydrology. John Wiley and Sons, Chichester. 869 pp

Beug, H.-J., 1961. Leitfaden der Pollenbestimmung. above) and 'cf' then you should add a note to explain what you mean.

D) It is not necessary to worry about obvious synonyms. Alternative names (e.g. Poaceae $=$ Gramineae) are standardized to conform with Flora Europaea. Morphological synonyms (e.g. Achillea type $=$ Matricaria type) are standardized to one of the pollen texts listed above.

Gustav Fischer Verlag, Stuttgart. 63pp

Faegri, K. and Iversen, J., 1989. Textbook of Pollen Analysis. John Wiley and Sons, Chichester. 328 pp Moore, P.D., Webb, J.A. and Collins, M.E., 1991. Pollen Analysis. Blackwell Scientific Publications, London. $216 \mathrm{pp}$

Punt, W. et al., 1976 - 1991. The Northwest European Pollen Flora, Volumes I - VI. Elsevier, Amsterdam. Reille, M., 1992. Pollen et Spores d'Europe et d'Afrique du Nord. Laboratoire de Botanique historique et palynologie, Marseille. $520 \mathrm{pp}$ 